\title{
COMPETITIVE ANALYSIS OF THE SUMATRA RUBBER INDUSTRY IN ASEAN FREE MARKET
}

\author{
Widyastutik*1 \\ *) Department of Economics, Faculty of Economics and Management, IPB University \\ Jl. Agatis, Campus of IPB Darmaga Bogor 16680, Indonesia
}

\begin{abstract}
The objectives of this research are to analyze (1) competitiveness and potential market attractiveness and business strength of rubber Sumatran in the ASEAN Market (2) Factors affect the Sumatran rubber industry competitiveness in the ASEAN market. The type of data used for this research development is primary and secondary data. Primary data were obtained from stakeholders, both exporters and producers in the rubber industry around North Sumatra and Riau. This research is using EPD and SEM PLS analysis methods. The Results of the RCA index shows that Indonesia ranks second after Vietnam for competitiveness. EPD analysis method shows that rubber and other rubber products are on the Lost Opportunity position in the ASEAN market. On the other hand, SEM PLS shows that in six latent variables, there are four variables that have an impact on Sumatran rubber industry competitiveness, two variables have a positive effect while the other two variables have a negative effect.
\end{abstract}

Keywords: rubber Sumatran, ASEAN Market, competitiveness and potential market, SEM PLS, RCA

Abstrak: Tujuan penelitian ini adalah menganalisis (1) daya saing dan potensi daya tarik pasar dan kekuatan bisnis komoditas karet di antara komoditas unggulan Sumatera lainnya di Pasar ASEAN (2) faktor-faktor yang memengaruhi daya saing industrt karet Sumatera di Pasar ASEAN. Jenis data yang digunakan dalam penelitian ini adalah data primer dan sekunder. Data primer diperoleh melalui penyebaran kuesioner dan FGD diperoleh dari para stakeholder baik eksportir maupun produsen di industri karet yang berlokasi di Sumatra Utara dan Riau. Metode analisis yang digunakan dalam penelitian ini adalah EPD (Export Product Dynamic) dan SEM PLS (Structural Equation Model Partial Least Square). Hasil analisis indeks RCA, Indonesia memiliki daya saing No 2 setelah Vietnam. EPD menunjukkan karet serta produk karet lainya berada pada posisi Lost Opportunity di pasar ASEAN. Hasil SEM PLS menunjukkan dari enam variabel laten, terdapat empat variabel yang berpengaruh terhadap daya saing industri karet Sumatera, dua variabel memiliki pengaruh yang positif dan dua variabel memiliki pengaruh yang negative.

Kata kunci: karet Sumatera, Pasar ASEAN, aya saing dan potensi daya tarik pasar, SEM PLS, RCA

${ }^{1}$ Corresponding author:

Email: widyastutik@apps.ipb.ac.id 


\section{INTRODUCTION}

ASEAN economic cooperation aims to accelerate economic growth, social progress, and cultural development in the Southeast Asian region. In its development, ASEAN economic cooperation is directed at the establishment of the ASEAN economic community (AEC). The 12th ASEAN Summit in 2007 agreed to the "Declaration on the Acceleration of the Establishment of an ASEAN Community by 2015" which produced the "Blueprint of the ASEAN Economic Community (AEC)". The AEC Blueprint contains strategic work plans in the short, medium, and long term up to 2015 towards the establishment of ASEAN economic integration (Ministry of Trade, 2015). Indonesia is one of the second largest producers of natural rubber after Thailand, Malaysia and Vietnam occupy the third and fourth position (www.indonesia-investments.com) However, Indonesia's rubber productivity is relatively less compared to the productivity of rubber plantations from other ASEAN neighboring countries, Thailand (1.8 tons/ha), Vietnam (1.7 tons/ha) and Malaysia (1.5 tons/ha) (www.indonesia-investments.com.). This will certainly affect the competitiveness of Sumatra's rubber in the facing the AEC.

One of the biggest natural rubber producing provinces in Indonesia is on Sumatra Island. Provinces in Sumatra such as South Sumatra, North Sumatra, and Riau are rubber-producing provinces in Indonesia (Arifin, 2005). For Sumatra, rubber is a leading export commodity besides palm oil. The area of smallholder plantations planted with rubber in Sumatra ranks second after palm oil.

The AEC commitment is predicted to bring challenges and opportunities for Indonesia and Sumatra in particular as rubber producers in Indonesia. The challenge of Indonesia's rubber productivity is lower than that of peer group countries so that it has an impact on Indonesia's rubber competitiveness. On the other hand, there are opportunities through reducing trade barriers that need to be utilized by Indonesia. Rubber producing regions such as Sumatra have the advantage of a very strategic geographical location. Sumatra and ASEAN are united by close geographical positions. Sumatra is very close to the ports of Singapore, Tanjung Pelepas in Johor Baru and Port Klang, also to Changi International Airport, Singapore, Bangkok, and Kuala Lumpur. All of these locations are the main nodes of trade traffic which strongly support the development of the industrial sector. Seeing its strategic location, there is a great opportunity for Sumatra to take advantage of the momentum of the AEC.

In addition, Sumatra also has a large trading potential due to its high comparative advantage for several agricultural commodities which are also potential contributors for regional income and economic drivers. Sumatra's export commodities to the global market in the 2011-2015 period were dominated by processed vegetable oil (36.54\%), natural rubber $(21.54 \%)$, tin (20.25\%) and animal oil (19.75\%).

The majority of Sumatra's main export commodities are extractive products in the form of raw materials. Extractive products in the form of raw materials have a low sensitivity to increased income compared to manufactured products. In theory, the\%age increase in demand for extractive products to increase revenue is relatively low. Some studies show a $1 \%$ increase in income will only increase demand for raw materials such as rubber by $0.5 \%$ while for manufactured products by $1.9 \%$ (Todaro, 2003).

Sumatra with the majority of ASEAN countries has natural resource endowments with relatively similar characteristics, namely extractive commodities such as plantations in this case rubber. If Sumatra continues to focus its exports on raw material products as it is now, other ASEAN countries such as Vietnam, the Philippines and Malaysia will become direct competitors. However, Sumatra rubber is faced with various challenges that affect competitiveness. A Bank Indonesia study (2016) shows that problems in the Sumatran rubber industry that affect competitiveness include damaged road infrastructure, high costs due to lack of infrastructures such as energy, fuel, and electricity. When the study was conducted, for Riau Province, road construction was constrained by the legality of spatial use. Labor wages will also affectcompetitiveness. Bank Indonesia's (2016) study findings for labor wages for rubber plantations in Sumatra are relatively high. Regulations related to the Governor's regulation that issued minimum wages for plantation products that buy oil palm which generates wages in the rubber industry also become high. Related to this description, it is relevant to conduct research on the competitiveness of Sumatra rubber in the ASEAN free market. 
Empirically, no studies have been found on the determinants of the competitiveness of the rubber industry in Sumatra within the AEC framework. Sumatra is vital, considering that Sumatra contributes $23 \%$ of the total Indonesian economy and accounts for $19 \%$ of the total GRDP of the manufacturing industry in Indonesia. Analysis of competitiveness in the scope of provinces in North Sumatra and East Java within the framework of the AEC has been carried out but for the case study of home industry MSMEs. The study was conducted by Sarma et al. (2016). Masri's (2015) analysis in a smaller scope of regional potential, namely in the city of Kupang in the face of the AEC. While a broader scale study was conducted by Bank Indonesia (2015) with the title "Analysis of Competitiveness and National Industry Strategy in the Era of the ASEAN Economic Community and Free Trade". Studies that focus on competitiveness and export of rubber have been carried out using secondary data such as research by Muharami and Novianti (2018) for exports to destination countries in Latin America, Choiruddin (2018) for exports of natural rubber in Indonesia, Malaysia and Thailand to the United States, Setyawati et al. (2104) for the demand of Indonesia's natural rubber exports to the United States using the multiple regression method. Utilizing the ECM (Error Correction Model) method, Nuraini (2018) analyzed the export of natural rubber to the United States. Research by Purnomowati et al. (2015) analyzed the export of natural rubber to the international world using the 2SLS method. In contrast to previous studies that made more use of secondary data, this study will use secondary data sourced from Cognos to analyze rubber competitiveness through the RCA index (Revealed Comparative Advantage) and EPD (Export Product Dynamic). With data sourced from Cognos, this research is able to compare the competitiveness of rubber in the scope of the islands, namely Sumatra with other ASEAN countries, in this case. Previous research, almost entirely comparing competitiveness between countries. Primary data through the distribution of questionnaires to actors in the rubber industry in Sumatra is used to further explore the factors that influence the competitiveness of Sumatra's rubber with the Diamond Porter approach which will be analyzed by SEM PLS (Structural Equation Model Partial Least Square). This study complements previous research which focuses more on secondary data. By analyzing primary data, this research is expected to capture the perceptions of business actors regarding the factors that affect the competitiveness of the Sumatran rubber industry.

Related to the above background, the objectives of this study are (1) analyzing the competitiveness and potential of market attractiveness and information on the strength of the rubber commodity business in the ASEAN Market; (2) analyzing the factors that influence the competitiveness of the Sumatran rubber industry in the ASEAN Market.

\section{METHODS}

Sumatra was taken purposively as a research location with the consideration that Sumatra is one of the largest natural rubber producing provinces in Indonesia. Provinces in Sumatra such as South Sumatra, North Sumatra, and Riau are rubber-producing provinces in Indonesia. For Sumatra, rubber is a leading export commodity besides palm oil. The area of smallholder plantations planted with rubber in Sumatra ranks second after palm oil. The research period is SeptemberOctober 2016.

The type of data used in this study consists of primary and secondary data. Primary data were obtained from distributing questionnaires and FGDs of stakeholders both exporters and producers in the rubber industry located in North Sumatra and Riau. The interview was guided by a questionnaire that was prepared to be able to answer the research objectives. Whereas secondary data is used from various sources as shown in Table 1.

Table 1. Data and data sources

\begin{tabular}{lc}
\hline Type of Data & Data Sources / Number of Respondents \\
\hline Secondary Data & Cognos \\
Volume and Value of Exports, Imports & BPS, WITS \\
$\begin{array}{l}\text { Other supporting secondary data } \\
\text { Primary Data }\end{array}$ & \\
$\begin{array}{l}\text { Distributing questionnaires and FGDs to company respondents } \\
\text { (rubber exporters and producers represented by managers and } \\
\text { company owners) }\end{array}$ & 5 respondents from Riau Province and 7 respondents \\
\end{tabular}




\section{Analysis Method}

Revealed Comparative Advantage (RCA) is an index used to Measure the relative advantages and disadvantages of certain commodities in a country that are reflected in its trading patterns, such as export market shares (Balassa, 1962). Based on the RCA method, trade between regions actually shows the comparative advantage possessed by a region.

In this study, the RCA method is used to Measure the position of competitiveness of Indonesian goods and services in ASEAN. The RCA formula is as follows:

$$
\mathrm{RCA}=(\mathrm{Xi} / \mathrm{Xt}) /(\mathrm{Wi} / \mathrm{Wt})
$$

Where: Xi (Value of Indonesia's i commodity exports to the country $\mathrm{j}$ ); Xt (Total value of Indonesia's exports to the country j); Wi (World's i commodity export value); Wt (Total value of world exports). There are two possible outcomes that can be obtained, namely RCA $>1$, which means that the country has a comparative advantage above the world average so that the commodity has strong competitiveness; RCA $<1$, which means that the country has a comparative advantage below the world average hence the country has weak competitiveness in the commodity.

\section{Export Product Dynamics (EPD)}

One of indicators that can provide a good picture of the level of competitiveness is Export Product Dynamics (EPD). This indicator measures the market position of a country's products for certain market objectives (Esterhuizen, 2006). An EPD matrix consists of market attractivveness and business strength information. This combination of market attarctiveness and business strength results in the position character of the product to be analyzed in four categories. The four categories are "Rising Star", "Falling Star", "Lost Opppotunity", and "Retreat". An overview of the position of competitiveness in the EPD analysis is shown in Figure 1. As for the meaning of a country's export market share (country i) and product market share (product $\mathrm{n}$ ) in world trade, namely:

Axis $\mathrm{x}$ : Export market share growth $\mathrm{i}=$

$$
\frac{\sum_{t=1}^{t}\left(\frac{X_{i n}}{X_{n}}\right)_{t} \times 100 \%-\sum_{t=1}^{t}\left(\frac{X_{i n}}{X_{n}}\right)_{t-1} \times 100 \%}{T}
$$

Y axis: Product market share growth $\mathrm{n}=$

$$
\frac{\sum_{t=1}^{t}\left(\frac{X_{n}}{X}\right)_{t} \times 100 \%-\sum_{t}^{t-1}\left(\frac{X_{n}}{X}\right)_{t-1} \times 100 \%}{T}
$$

Where: $\mathrm{X}$ (export volume); $\mathrm{T}$ (number of years); $\mathrm{t}$ (year t).

The EPD analysis method has been used to see the position of rubber commodity competitiveness as conducted by Novianti and Ella (208) for exports to China, Muharami and Novianti (2018) for exports to Latin American destination countries, Choiruddin (2018) for the case of export competitiveness Indonesia, Malaysia and Thailand natural rubber to the United States.

\section{Diamond Porter Theory}

Porter (1990) states that there are four factors that make up competitive advantage known as Diamond Porter, namely factor conditions; Request; related and supporting industries; company strategy, structure and competition plus two external factors namely government and opportunity. Diamond Porter's competitive advantage theory is used in this study because it is relevant to capture various variables which are then derived into various indicators to analyze the factors that affect Sumatra's competitiveness in ASEAN free trade.

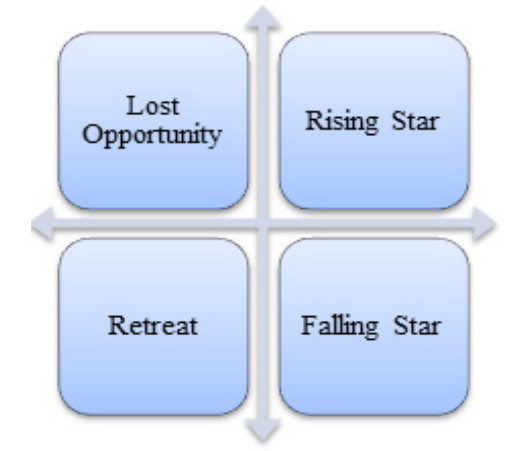

Figure 1. Market Attractiveness and Business Strength in EPD (the $\mathrm{x}$-axis represents an increase in the export market share of these products in world trade; the y axis describes the country's increasing market share in world trade). 


\section{Structural Equation Model (SEM) Analysis}

In this study Structural Equation Model (SEM) analysis is used as a statistical technique that is able to analyze latent variables, indicator variables and Measurement errors directly (Sitinjak and Sugiarto, 2006; Byrne 2001). The data processing method used in this study is the Partial Least Square (PLS) method through the first order approach (Widarjono, 2015). The PLS-SEM path analysis model consists of two elements namely a structural model or inner model and a measurement model or outer model. The inner model is a variable condition factor, demand, related and supporting industries, strategy, structure and competition, the role of government and opportunity. While the outer model illustrates the relationship between latent variables and indicator variables as shown in Figure 2. For example based on Figure 2, the outer model for factor conditions is the condition of infrastructure, raw materials and natural resources, labor, technology and capital.

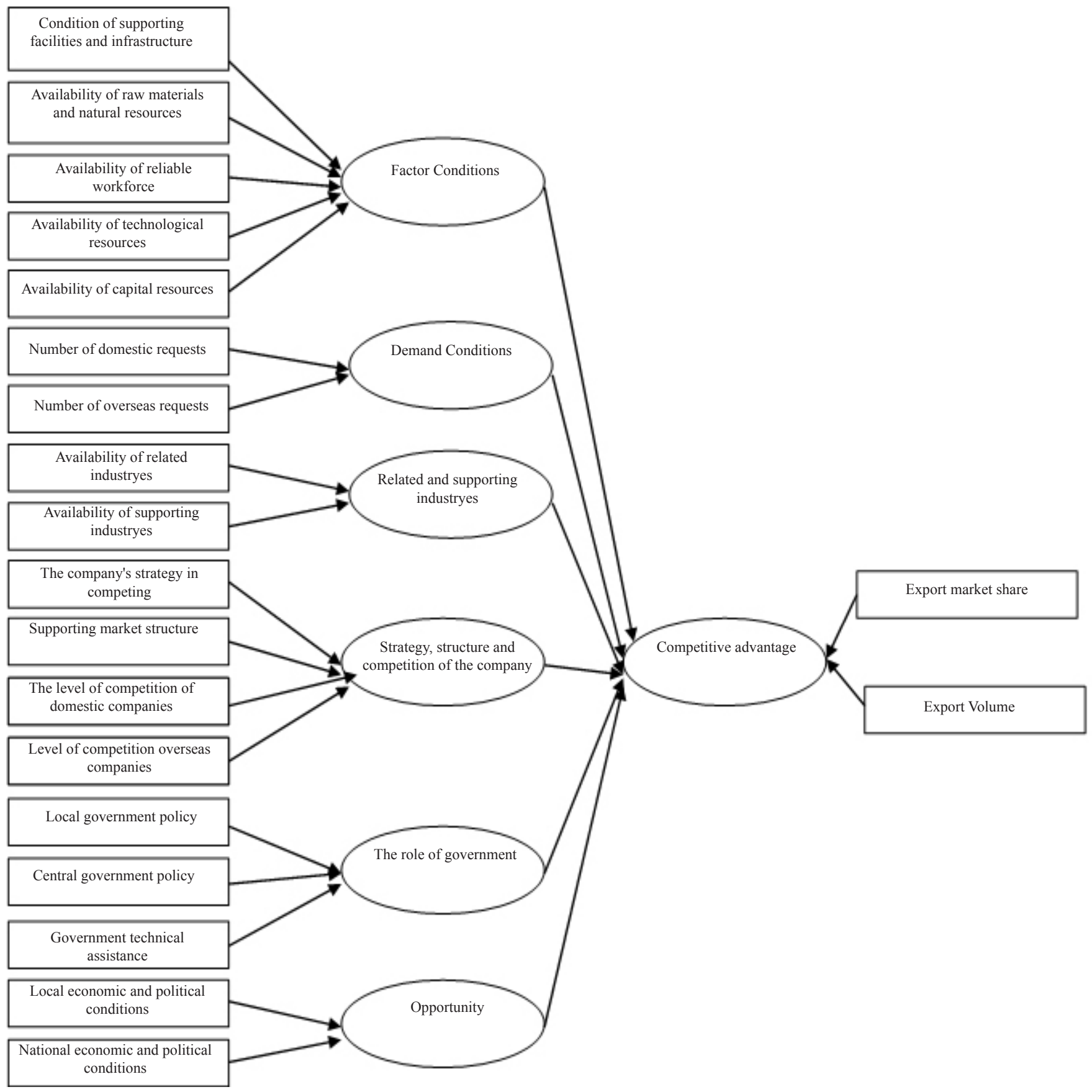

Figure 2. Research Design of SEM Model Competitiveness of Sumatra Rubber Industry in the AEC Framework 


\section{RESULTS}

In this study, the number of rubber company respondents were 5 respondents from Riau Province and 7 respondents from North Sumatra. Business categories whom dominated respondents were as producers and exporters of rubber $(75 \%)$. Most of the respondents, around $50 \%$ of respondents stated that their main product type was chunks of rubber (SIR 10 and 20) while $33 \%$ of respondents stated that the main types of products were conventional rubber (RSS and latex).

\section{Sumatra Rubber Competitiveness in the ASEAN Market: RCA and EPD Approach}

With data sourced from Cognos, this study can compare the rubber competitiveness in the scope of the islands, namely Sumatra with countries of ASEAN members. Based on Table 2, the competitiveness of Sumatra's natural rubber commodity is higher compared to other ASEAN member countries except Vietnam. Among other ASEAN countries, Vietnam had the highest competitiveness, 104.77, followed by Sumatra, at 65.31. Indonesia has not been able to become the world's major producer of rubber because the area of rubber plantations is dominated by smallholder rubber plantations that have low productivity. Low productivity was allegedly due to the number of rubber plants that are old, damaged and unproductive, the use of seeds that are not superior clones (Permana and Izzaty, 2010).

Analysis of Export Product Dynamics (EPD) was also conducted to identify market attractiveness and information on the strength of the Sumatran rubber business in the ASEAN Market in the 2011-2015 period. The market attractiveness matrix is calculated based on the growth of product demand for a particular market destination, where information on business strength is measured based on the growth of a country's market share in a particular market destination. It was identified that only Sumatra synthetic latex rubber showed a trend of increasing market share in the ASEAN market during the 2011-2015 period. The increase in the market of Sumatra's synthetic rubber market and the total market share of Sumatra to the ASEAN Market was also accompanied by an increase in the growth of the total share of Sumatra's exports to ASEAN. Therefore, the position matrix of the two products is in the Rising Star quadrant.
Even so, there was a decline in the average growth of Sumatran rubber commodities and their derivatives classified as raw materials such as natural rubber (-12.13), rubber tires $(-0.24 \%)$, and other rubber products $(-10.76 \%)$ of total export commodities in the market ASEAN (Table 3). The decline in demand for leading commodities is an indication of the slowing economic growth experienced by the majority of ASEAN countries due to rebalancing policies undertaken by China as a major trading partner. In addition, the majority of ASEAN member countries are net commodity exporters of international countries, so that falling international commodity prices will reduce economic growth and result in weakening purchasing power. Therefore, the total demand for Sumatran rubber commodity imports in the ASEAN region has decreased. The impact of these two indicators resulted in the majority of Sumatra's rubber commodities being in the position of Lost Opportunity. In addition, the position of Lost Opportunity also shows that the dynamics of export performance.

This shows that although Sumatra's rubber competitiveness is relatively high compared to other ASEAN countries, it has begun to lose its market, especially for natural rubber, tires from rubber and other rubber products. This is certainly a challenge for Sumatra so that the lost opportunity position in the three rubber HS products can shift to the rising star position.

\section{Determinants of Sumatra Rubber Industry Competitiveness in the AEC Framework}

Table 4 is the result of the PLS SEM model after removing invalid variables. The indicator used is when outer loading is above 0.4 and is significant. In factor conditions, there are four indicators that form latent variables of factor conditions, namely the condition of supporting facilities, raw materials, labor and energy. This shows that the four indicators are those that make up the factor condition variable with the important indicator being raw materials. In the rubber industry, the availability and quality of raw materials is an important factor for the sustainability of the rubber processing industry, especially at this time where the price of rubber is falling hence many farmers are reluctant to tap their rubber trees. 
Table 2. Competitiveness analysis of sumatra's natural rubber exports compared to other ASEAN countries, 2015

\begin{tabular}{ccccccc}
\hline \multirow{2}{*}{ HS Code } & \multicolumn{7}{c}{ RCA } \\
\cline { 2 - 7 } & Sumatera & Malaysia & Singapura & Thailand & Vietnam & Filiphina \\
\hline 231 & 65.31 & 4.01 & 0.25 & 18.33 & 104.77 & 4.13 \\
\hline
\end{tabular}

Table 3. Dynamics of sumatra rubber export products in the ASEAN Free Market in 2011-2015

\begin{tabular}{llccc|}
\hline HS Code & HS Description & X-axis average growth & X-axis average growth & Matrix Position \\
\hline 231 & Natural Rubber & -12.12 & 4.66 & Lost Opportunity \\
625 & Rubber Tires & -0.24 & 4.66 & Lost Opportunity \\
232 & Synthetic latex rubber & 473.79 & 4.66 & Rising Star \\
629 & Other Rubber Products & -10.75 & 4.66 & Lost Opportunity \\
\hline
\end{tabular}

Table 4. Loading factors of each indicator on latent variables

\begin{tabular}{llcc}
\hline Indicators & Outer loading & t-value & Explanation \\
\hline Condition of supporting infrastructure (x1.02) & 0.64 & 6.86 & Valid \\
Raw material (x1.03) & 0.85 & 17.68 & Valid \\
Labor (x1.05) & 0.82 & 18.10 & Valid \\
Energy (x1.07) & 0.69 & 12.17 & Valid \\
Domestic rubber demand (x2.01) & 1 & - & Valid \\
Rubber related industry (x3.01) & 0.93 & 3.06 & Valid \\
Rubber supporting industry (x3.02) & 0.96 & 3.09 & Valid \\
Structure of the rubber market and its derivative products (x4.02) & 0.80 & 13.19 & Valid \\
Level of competition of domestic companies (x4.03) & 0.93 & 86.63 & Valid \\
Level of competition overseas companies (x4.04) & 0.57 & 8.23 & Valid \\
Ease of bureaucracy and institutions (x5.04) & 1 & - & Valid \\
Regional economic and political conditions (x6.01) & 0.60 & 5.56 & Valid \\
National economic and political conditions (x6.02) & 0.60 & 5.56 & Valid \\
ASEAN economic and political conditions (x6.03) & 0.60 & 10.14 & Valid \\
Capital inflow from ASEAN (x6.09) & 0.92 & 45.74 & Valid \\
Capital outflow/investment to ASEAN (x6.10) & 0.92 & 45.74 & Valid \\
Export market share (y1.01) & 0.73 & 3.93 & Valid \\
Export volume (y1.02) & 0.86 & 31.83 & Valid \\
\hline
\end{tabular}

In the condition of demand, there is only one indicator, the condition of domestic demand. With the condition of the sluggish world economy which has caused world rubber prices to drop dramatically, the Indonesian rubber industry expects an increase in domestic demand. The government has called on businesses to use natural rubber as a mixture for the manufacture of highways and ports. With the use of natural rubber for asphalt mixture, the construction of roads and ports can increase domestic rubber demand which will also increase domestic rubber prices.

In the latent variables supporting and related industries latent variables, the one which form the variables are supporting and related industries. The greatest value is in the supporting industry. This shows that the rubber industry needs supporting industries so that the rubber industry can develop.

Indicators that make up the latent variables of strategy, structure and competition are market structure, the level of competition with domestic companies and the level of competition with foreign companies. With the biggest loading value is the level of competition of domestic companies. The level of competition of domestic companies is relatively high because companies in the rubber industry are generally Domestic Investment companies. In the government regulations and policies latent variables, there are only one valid indicator, namely ease of bureaucracy and institutions, especially 
concerning licensing. The rubber industry requires various kinds of licensing so this factor is considered important for the rubber industry players.

In the opportunity latent variable, there are five indicators that make up this variable, namely the regional, national, ASEAN political conditions, capital flows from ASEAN and capital outflows. The highest factor loading value is capital flow from ASEAN and capital outflow. This shows that the ease of capital flows both in and out is an important factor in the rubber industry, especially in Sumatra. Capital flows into the rubber industry as an investment in the future will increase the competitiveness of the rubber industry in Sumatra. In detail, loading the factors of each indicator against latent variables can be seen in Table 4 .

Evaluation models for latent variables use composite reality (CR) and average variance extracted (AVE) indicators. Composite reality (CR) calculates internal consistency with a limit above 0.7 while the average variance extracted (AVE) looks at how the construct variance can be explained from the selected indicators with a limit above 0.5. From the results of the two indicators, all valid latent variables are indicated by CR values above 0.7 and AVE values above 0.5 . For the whole model, the indicator R2 is 0.9689 . Based on Chin (1998), R2 in this study belongs to the substantial category. The R2 criteria in PLS-SEM consist of three classifications, namely R2values $0.67,0.33$ and 0.19 as substantial, moderate and weak. Changes in the value of R2 can be used to see whether the influence of exogenous latent variables on endogenous latent variables has substantive effects (Chin, 1998).
The six latent variables, there are four variables that influence competitive advantage, two variables have a positive effect and two variables have a negative effect (Table 5). Demand conditions have a positive influence on competitive advantage, one indicator that shapes demand conditions is the demand for the domestic rubber industry. Government policies addressing declining foreign demand by increasing domestic demand through requiring the use of domestic rubber for the manufacture of roads or shipyards when increasing the competitiveness of the Sumatran rubber industry within the AEC framework.

The second positive latent variable is opportunity. The indicator that forms the opportunity variable and has the highest factor loading value is capital inflows and outflows. Respondents considered that the increase in inflow investment, especially from overseas, would increase the competitiveness of the Sumatran rubber industry. FDI can increase Sumatra's economic growth because it is an important source of economic growth. FDI can increase capital, income and employment. In addition, FDI also impacts spillover to other companies through the advanced technology it carries. Research by Yuliani et al. (2019) found the existence of horizontal and vertical Spillover FDI to the Value Added of 18 domestic food industry sub-sectors using agricultural sector inputs. More details Yuliani et al. (2019) also conducted research on the impact of FDI spillover, technology, and company size on productivity in the food industry. Increased productivity and added value will certainly also have an impact on increasing product competitiveness.

Table 5. Effect of latent variables on competitiveness in the rubber industry

\begin{tabular}{llcc}
\hline Latent variable constructive coefficien & Construct Coefficient & t-value & Explanation \\
\hline Factor conditions & -0.68 & 11.40 & Significant \\
Demand conditions & 0.12 & 2.14 & Significant \\
Related and supporting industries & 0.12 & 0.93 & Not Significant \\
Strategy, structure and competition & -0.40 & 7.89 & Significant \\
Government regulations and policies & 0.09 & 1.35 & Not Significant \\
Opportunity & 0.11 & 2.66 & Significant \\
\hline
\end{tabular}


The insignificance of the latent variables of the related and supporting industries is in line with the findings of the field, which shows that $20 \%$ of respondents disagreed and $35 \%$ of respondents strongly disagreed that rubber related industries are available as shown in Figure 3. Not only related industries are needed to develop the rubber industry, supporting industries such as banking, transportation and communication sectors are also necessary. The banking sector functions as a lending institution as well as an institution that helps increase buying and selling transactions (international trade). There are $25 \%$ of respondents stated strongly disagree and $20 \%$ disagree that there is a supporting industry of rubber companies in Sumatra. The importance of the service sector (banking, transportation, communication, logistics and distribution) to the trade in goods / commodities is in line with Widyastutik's findings (2019).

The insignificance of government regulations and policies is also in line with the findings of the field which show that almost $40 \%$ of respondents said that they did not agree that there was technical assistance and support to the rubber industry. An interview with PT HKL stated that socialization or coaching in the rubber industry is very necessary because companies learn more from rubber consumers, not from the government. Although central government policies are considered supportive, respondents provide a perception that regional policies are relatively less supportive. Based on Figure 4, 42\% disagreed and $17 \%$ strongly disagreed if government policies supported the rubber industry. One of the policies deemed unsupportive is the policy to impose the same minimum wage between the rubber and palm oil industries.

Latent variables that have negative construct coefficients are condition factors and strategies, structure, and competition. This shows that although the condition of the factors (both from raw materials, labor, capital and strategy, structure, and competition) are already good, they have not been able to increase the competitiveness of the Sumatran rubber industry in the ASEAN market. There are other factors that have more influence on the competitiveness of the Sumatran rubber industry within the AEC framework.

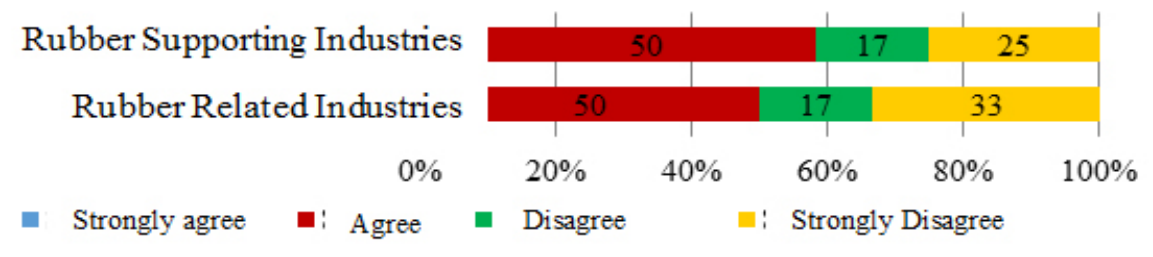

Figure 3. Respondents' perceptions regarding support from related industries and supporters of the sumatra rubber sector

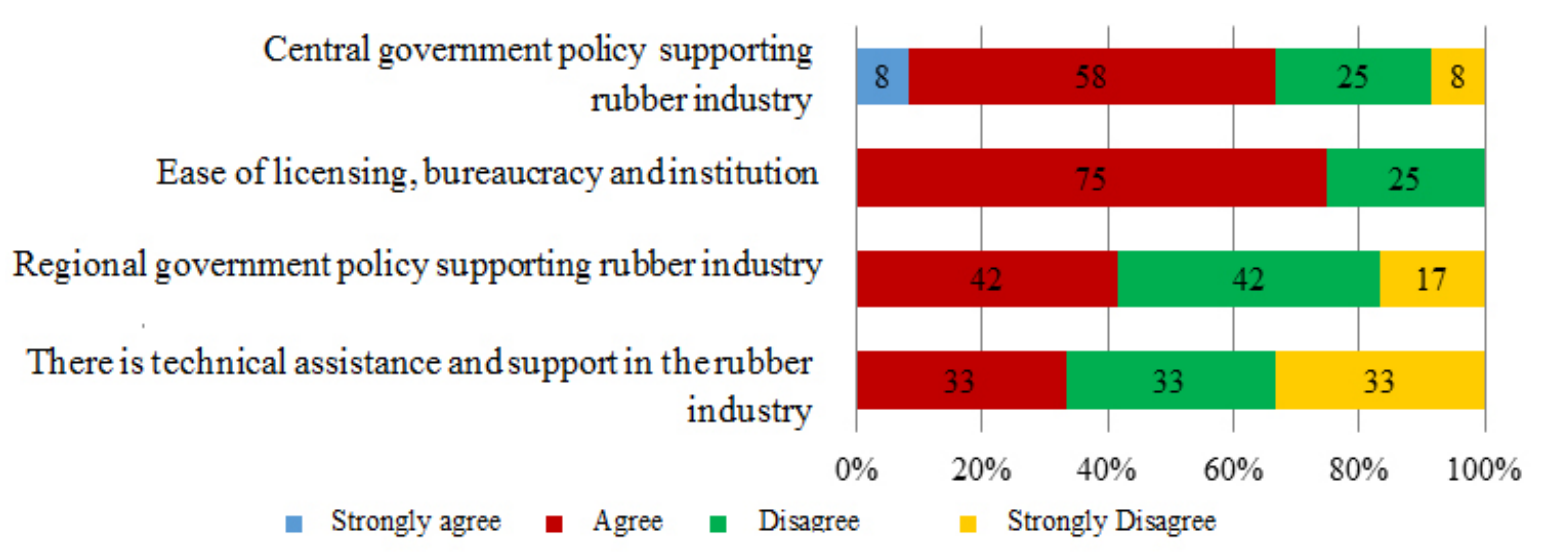

Figure 4. Government regulations on the rubber industry in Sumatra 


\section{Managerial Implications}

Studies show that the demand factor has a significant positive effect on the competitiveness of Sumatran rubber. To increase rubber demand, the government needs to develop industries that use rubber raw materials. Regarding the downstream strategy of processed rubber products, the government needs to provide fiscal incentives in the form of tax holidays for the downstream rubber industry.

Increasing FDI will increase the competitiveness of the Sumatran rubber industry. The increase in FDI also had an impact in the form of spillover effects on other companies through advanced technology. With the spillover effect through advanced technology, the rubber industry and its derivatives can operate more efficiently thus encouraging the improvement of Sumatra's rubber competitiveness. To attract FDI, tax regime improvements such as tax incentives need to be done. In addition, the government needs to guarantee interest rates and exchange rates that attract investors. Indonesia and its trading partners need to utilize various FTA cooperation schemes related to investment. From the corporate side, increasing the capacity of human resources and technology will encourage an increase in the spillover effect of FDI.

\section{CONCLUSIONS AND RECOMMENDATIONS}

\section{Conclusions}

Sumatra rubber has comparatively strong competitiveness. This can be seen from the results of the calculation of the value of RCA which has a value of more than 1. The results of the RCA analysis show that Sumatra's rubber competitiveness ranks number 2 after Vietnam among other ASEAN members. However, judging from the market's attractiveness and information on the business strength of Sumatra's leading commodities in the ASEAN market, only synthetic latex rubber is in a rising star position, which shows that Sumatra has experienced an increase in the export market share of these products along with an additional ASEAN market share. While for raw materials such as natural rubber, rubber tires and other rubber products tend to be smaller than the total export commodities in the ASEAN Market thus they are in the matrix of Lost Opportunity position in the ASEAN market. This indicates natural rubber, rubber tires and other rubber products have a weak competitive advantage in the export market.

From the results of the PLS-SEM model analysis, demand and opportunity conditions have a significant and direct effect on the competitiveness of the rubber industry in the presence of the AEC. For the opportunity variable that explains the unidirectional relationship with the competitiveness of the rubber industry is the flow (investment) in and out of ASEAN, where business actors consider that investment entering Indonesia, especially from abroad, is still lacking in the rubber industry, especially in the downstream industry. Currently, rubber processing companies are generally domestic investment companies. In addition to the two variables, there are other variables that have a significant but negative effect (not in the same direction) on the competitiveness of the palm oil industry after the AEC, namely factor conditions, and strategy, structure and competition.

\section{Recommendations}

To increase the competitiveness of the rubber industry, efforts are needed to increase the domestic demand for rubber products to anticipate the decline in rubber demand from foreign markets. Not only for road construction (asphalt mix), a strategy for the processing of rubber processed products such as tire manufacturing, rubber gloves, rubber yarn, footwear, retread tires, medical gloves, and other relevant tools. The development of the downstream industry will increase the value-added of rubber commodities, bearing in mind that $85 \%$ of Indonesia's rubber exports are in the form of raw rubber.

The opportunity variable significantly influences the competitiveness of the Sumatran rubber industry within the AEC framework. The factor that reflects the opportunity variable is an indicator of regional, national, and ASEAN political-economic conditions supporting the rubber industry. This implies that the government needs to guarantee the stability of the regional, national and even ASEAN political economy to support the competitiveness of the Sumatran rubber industry within the AEC framework. Besides these factors, FDI also affects the competitiveness of the Sumatran rubber industry within the AEC framework. Related to this, Sumatra needs to increase. Its attractiveness so that foreigners would enter and invest in the Sumatra rubber industry. 


\section{REFERENCES}

Arifin B. 2005. Supply chain of natural rubber in Indonesia. Jurnal Manajemen dan Agribisnis 2(1): 1-16.

Bank Indonesia. 2015. Analisis Daya Saing dan Strategi Industry Nasional di Era Masyarakat Ekonomi ASEAN dan Perdagangan Bebas. Jakarta: Bank Indonesia.

Byrne BM. 2001. Structural Equation Model (SEM) with AMOS: Basics, Concepts, Applications, and Programming. Lawrence Erlbaum Associates Publishers.

Chin WW. 1998. The partial least squares approach to structural equation modelling. Modern Method fot Business Research, 295-336.

Esterhuizen D. 2006. AECsuring Analysing Competitiveness in the Agribusiness Sector: Methodological and Analytical Framework. Petroria: University of Petroria.

Kementerian Perdagangan. 2015. Мепијu ASEAN Community. Jakarta: Kementerian Perdagangan.

Masri M. 2015. Analisis Potensi Daerah dalam Rangka Menghadapi Masyarakat Ekonomi ASEAN. Kupang: Universitas Katolik Widya Mandira Kupang.

Muharami G, Tanti N. 2018. Analisis kinerja ekspor komoditas karet indonesia ke Amerika Latin. Jurnal Agribisnis Indonesia 6(1): 1-12. https:// doi.org/10.29244/jai.2018.6.1.1-12.

Novianti T, Ella H. 2008. Analisis penawaran ekspor karet alam indonesia ke negara China. Jurnal Manajemen dan Agribisnis 5(1):40-51.

Nuraini, A. 2018. Analisis faktor yang memengaruh ekspor karet indonesia ke Amerika Serikat pada Tahun 1980-2015 [Skripsi]. Yogyakarta: Fakultas Ekonomi, Universitas Islam Indonesia.

Permana SH, Izzaty I. 2010. Daya saing ekspor barangbarang dari karet. Jurnal Ekonomi dan Kebijakan Publik 2(1): 153-188.
Porter ME. 1990. The Competitive Advantage of Nations. New York: Free Press. https://doi. org/10.1007/978-1-349-11336-1.

Purnomowati $\mathrm{H}$ et al. 2017. Analisis permintaan karet alam Indonesia di pasar internasional. Jurnal Agraris 1(2):1-13. https://doi.org/10.18196/ agr.1217.

Sarma M, Herien P, Dedi CS. 2016. Kesiapan Provinsi dalam Pelaksanaan AEC-Utamanya Mekanisme Jejaring dan Pendampingan Industry Rumahan: Studi Kasus di Provinsi Sumatera Utara dan Jawa Timur. Laporan Penelitian Kerjasama Kementerian Pemberdayaan Perempuan dan Perlindungan Anak RI dan LPPM IPB. Bogor:

Kementerian Pemberdayaan Perempuan dan Perlindungan Anak RI dan LPPM IPB.

Setyawati IK, Yeong-Shenn L, Budi S. 2014. Analisis permintaan ekspor karer alam indonesia ke Amerika Serikat. AGRISE XIV(2):98-106.

Sitinjak TJ, Sugiarto R. 2006. LISREL. Yogyakarta: Penerbit Graha Ilmu.

Tambunan T. 2003. Industryalisasi di Negara Sedang Berkembang, Kasus Indonesia. Jakarta: Ghalia Indonesia.

Todaro MP. 2003. Pembangunan Ekonomi di Dunia Ketiga. Alih Bahasa: Aminuddin dan Drs. Mursid. Jakarta: Ghalia.

Widarjono A. 2015. Analisis Multivariat Terapan. Yogyakarta: UPP STIM YKPN.

Yuliani F, Hermanto S, Widyastutik, Amzul R. 2019. Dampak FDI vertikal dan horizontal terhadap nilai tambah 18 sub sektor industry makanan domestik. Buletin Ilmiah Litbang Perdagangan 13(2):233-258.https://doi.org/10.30908/bilp. v13i2.422.

Yuliani F, Hermanto S, Widyastutik, Amzul R. 2019. The impact of foreign direct investment spillover, technology and firm size on the productivity of domestic firm in food industry. International Journal of Economics and Financial Issues 9(3): 287-296. https://doi.org/10.32479/ijefi.7905. 